early Holocene atmospheric and ocean temperatures in the AP region were higher than those measured in recent decades. However, if IPCC predictions of increased atmospheric temperatures in the coming decades continue to apply to the AP we can expect that its ice shelves will continue to retreat (Hodgson et al., 2006).

Marine sediment cores collected from the northeast of South Georgia, the Scotia Sea and down both sides of the AP are also revealing spatial and temporal changes in oceanographic variables along the AP transect. Initial results, focussing on changes in sea-ice extent, suggest an early retreat of summer sea ice across the Scotia Sea, with the average summer sea-ice margin being close to its Holocene position before $21 \mathrm{cal}$ kyr BP. In contrast, the winter sea-ice limit was stable north of the Falkland Trough until at least $19 \mathrm{cal}$ kyr BP (Allen et al., 2005). This is similar to records from the eastern Atlantic and Indian sectors of the Southern Ocean that also document a pre-LGM summer sea-ice maximum and early retreat to a near-modern extent by the LGM (Crosta et al., 1998; Gersonde et al., 2005). This means that the seasonal area of sea-ice growth and decay would have been more than double that of today's Southern Ocean, producing a much larger expanse of seasonally open-water than most models suggest. The associated impacts on Southern Hemisphere albedo and ocean-atmosphere energy transfers would have had a profound influence on feedback-dynamics during the glacial transition and are being further explored.

Our ice, lake and marine records have been selected for their high resolution and to facilitate detailed time-series analyses to determine the timing and phasing of climate events through the Holocene. Our activities also compliment a recent intensification of paleoecological research in southernmost South America and to the new and exciting ice core records from central East Antarctica (produced) and West Antarcica (in progress). Together with records from collaborating groups, these activities should give us a comprehensive view of how the climate system in the AP has behaved, and how it is linked to global climate via $\mathrm{CO}_{2}$, orbital forcing, major modes of atmospheric circulation, ocean circulation and sea ice.

Further information: www.antarctica.ac.uk/bas_ research/current_programmes/cache.php www.holant.ugent.be/

Selected links:

www-lgge.ujf-grenoble.fr/

www.hamilton.edu/news/exp/antarctica/2004/ faculty.html

http://shaldril.rice.edu/

www.salsa.uni-bremen.de/

www.pages-igbp.org/science/initiatives/lotredsa/

\section{References}

Allen, C. S., Pike, J., Pudsey, C. J. and Leventer, A., 2005: Submillennial variations in ocean conditions during deglaciation based on diatom assemblages from the southwest Atlantic, Paleoceanography, 20: PA2012 10.1029/2004PA001055.

Hodgson, D. A., Bentley, M. J., Roberts, S. J., Smith, J. A., Sugden, D. E. and Domack, E. W., 2006: Examining Holocene stability of Antarctic Peninsula Ice Shelves, Eos Transactions, American Geophysical Union, 87: 305-312.

Smith, J. A., Bentley, M. J., Hodgson, D. A., Roberts, S. J., Leng, M. J., Lloyd, J. M., Barrett, M. J., Bryant, C. and Sugden, D. E., 2007: Oceanic and atmospheric forcing of early Holocene ice shelf retreat, George VI Ice Shelf, Antarctica Peninsula, Quaternary Science Reviews, 26: 500-516.

Vaughan, D. G., Marshall, G., Connolley, W. M., Parkinson, C., Mulvaney, R., Hodgson, D. A., King, J. C., Pudsey, C. J., Turner, J. and Wolff, E., 2003: Recent rapid regional climate warming on the Antarctic Peninsula, Climatic Change, 60: 243-274.

\title{
The Lake Malawi Scientific Drilling Project
}

\section{Christopher A. Scholz}

Department of Earth Sciences, Syracuse University, USA; cascholz@syr.edu

In 2005, an international team of researchers undertook an ambitious plan to drill two sites in Lake Malawi $\left(9^{\circ}-14^{\circ} \mathrm{S}\right)$, in water depths of 592 and $359 \mathrm{~m}$ in the central and northern basins of the lake. Lake Malawi is located in the southern end of the western branch of the East African Rift System (Fig. 1, inset). It extends along more than $550 \mathrm{~km}$ of the rift valley, and with a depth of $700 \mathrm{~m}$, it is the second-deepest lake in Africa. Along with Lake Tanganyika, Lake Malawi contains one of the longest highresolution paleoclimate records of the continental tropics.

The primary objective was to obtain a continuous, high-resolution (annualdecadal) record of past climates in the continental tropics, and to then determine if tropical African climate responded to changes in low-latitude precessional insolation (23-19 kyr), or to high-latitude ice volume (100 kyr and $41 \mathrm{kyr}$ ) forcing, during the late Pleistocene.

The project initially faced very difficult engineering and logistical challenges. A $160 \mathrm{ft}$ fuel barge was used as the drilling platform, which was stabilized by a portable dynamic positioning system designed to maintain the position of the barge for weeks at a time (Fig. 1). The drilling operation involved 26 personnel aboard the

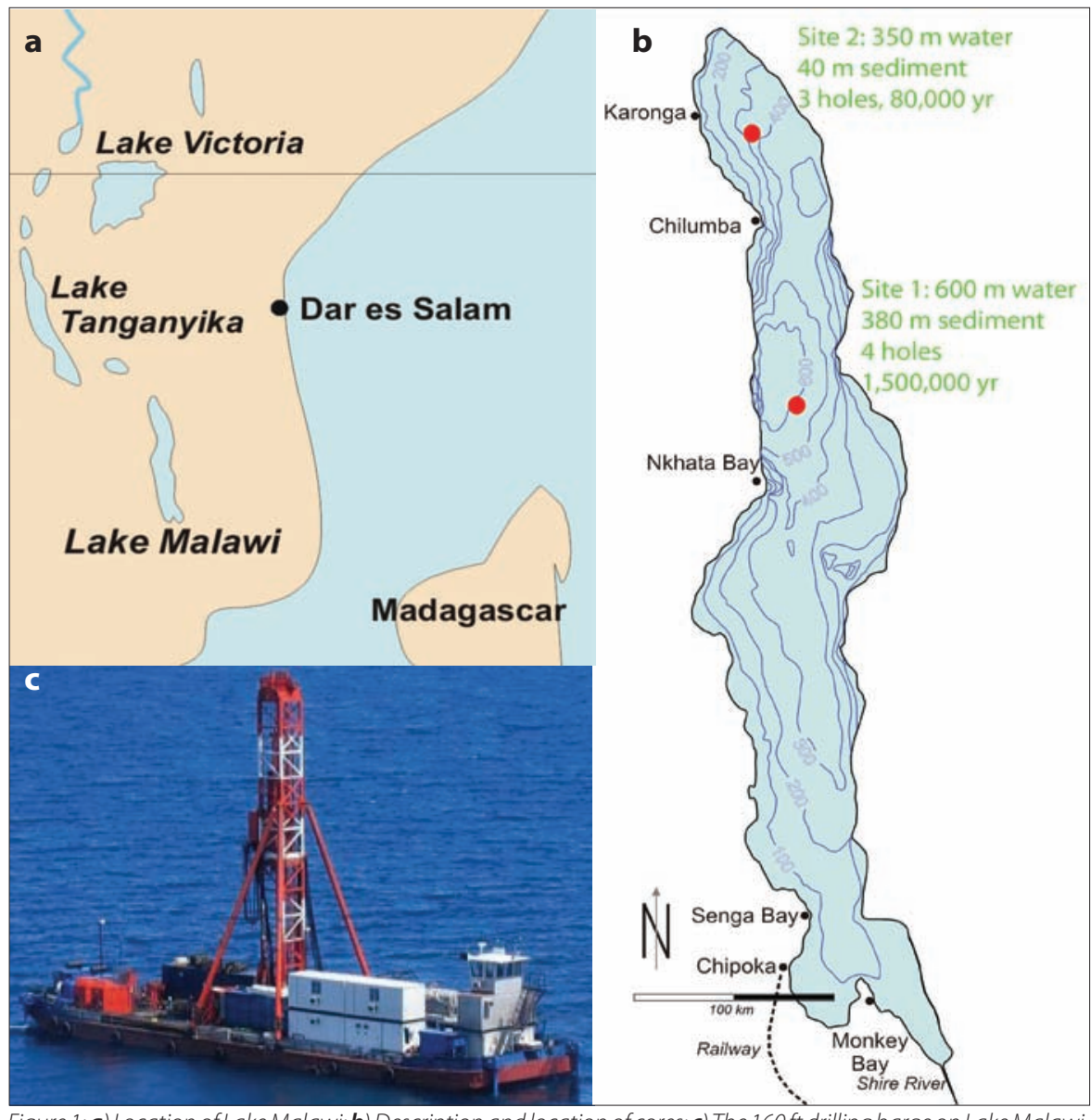

Figure 1:a) Location of Lake Malawi; b) Description and location of cores; $\mathbf{c})$ The $160 \mathrm{ft}$ drilling barge on Lake Malawi, where 26 members of the drill team, science team and ships crew lived for six weeks in 2005. Image courtesy of 1. Castaneda, University of Minnesota. 


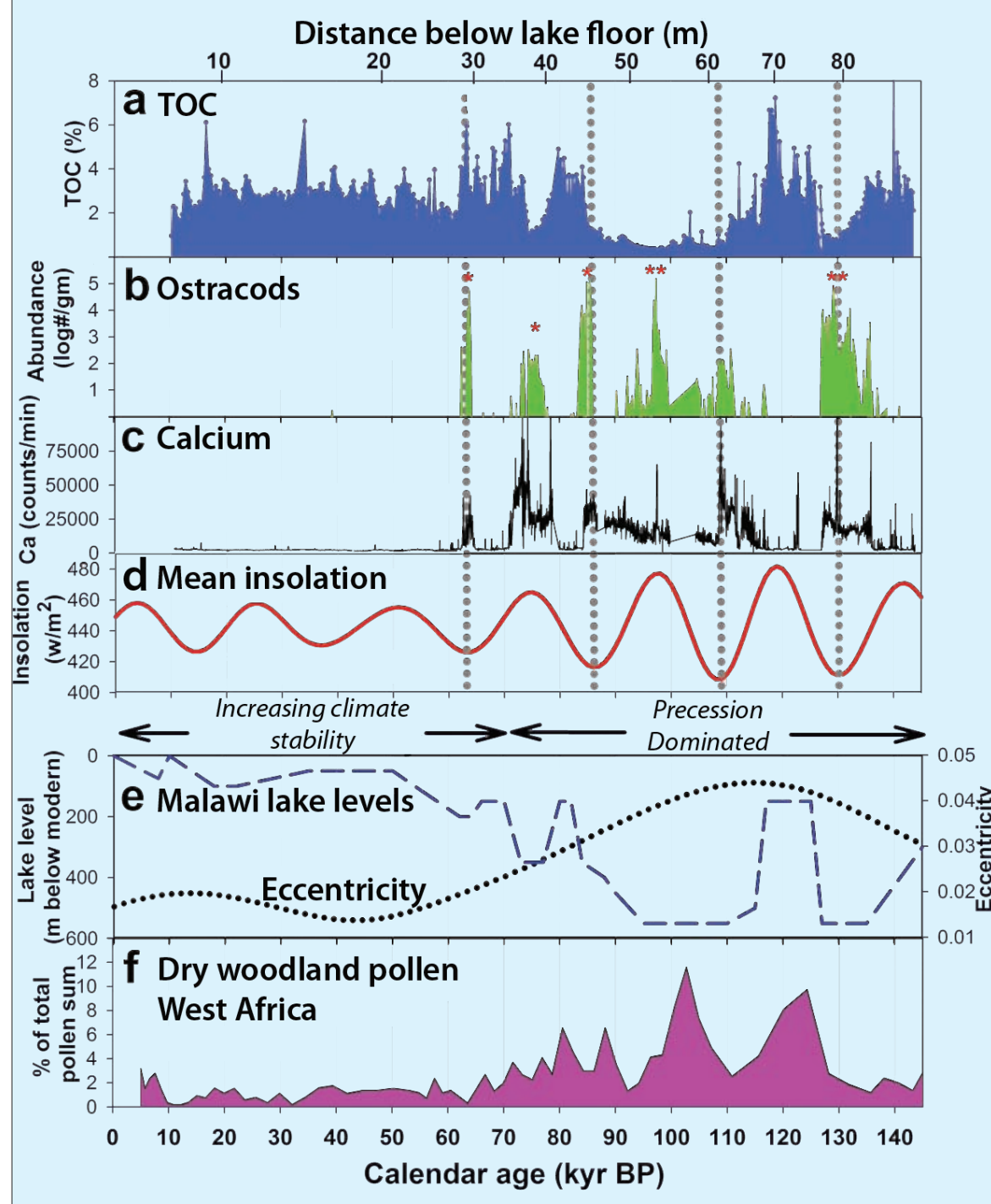

Figure 2: Summary of Lake Malawi lake-level indicators from site 1 cores, with orbital forcing and marine records. a) Total Organic Carbon (TOC) - high values indicate highstand conditions and bottom water anoxia; $\boldsymbol{b}$ ) Ostracod abundance - * core intervals of profundal taxa, ** core intervals of littoral zone taxa and lake shoreline close to drill site. Ostracods are only present when the lake is shallow and bottom waters are oxygenated; $\mathbf{c}) \mathrm{Ca}$ abundance - indicates periods of calcium carbonate precipitation (i.e. during severe lowstand, or high salinity events); d) Local mean insolation $\left(10^{\circ} \mathrm{S}\right)$ at the end of the dry season (1 Oct-1 Dec); Vertical dotted lines signify precession-dominated insolation minima; $\boldsymbol{e}$ ) Malawi lake level vs. eccentricitiv; f) Dry woodland pollen record from marine core GeoB 1016, West Africa, demonstrating comparable climate signals to those observd in Lake Malawi. (modified from Scholz et al., 2007)

barge, working continuously in 12-hour shifts and was supported by three supply ships.

More than $623 \mathrm{~m}$ of core was recovered from seven holes at two sites. Three cores were collected from the high-resolution site (extending back $~ 80 \mathrm{kyr}$ ), two cores were obtained from the deep site (covering the past ca. $150 \mathrm{kyr}$ ) and a single core was collected from the deep site to $380 \mathrm{~m}$, covering as much as a million years or more in age. Sample material recovered included a variety of laminated and homogenous algal-rich mud (dominantly clay) in zones of alternating dry/dense and soft/high-water content material; cemented siltstone; volcanic ash horizons; and fine-grained well-sorted sands at the base of holes at both sites. Laminations from late-Pleistocene and Holocene sediments have been shown to be varves, and thus annual records may be recovered from many discrete intervals over the cored interval.

Prior to drilling, preliminary studies were undertaken including detailed analyses of short cores and extensive seismic reflection datasets (Fig. 2). The earlier of this southern hemisphere tropical site has linkages to high-latitude climate, but evidence of very high-amplitude lakelevel shifts also implied possible orbital control of effective moisture in the lake's vast catchment. The first results from drill core analyses indicate that on two occasions, between 135 and 75 kyr, water levels dropped to more than $550 \mathrm{~m}$ below modern levels. Lake level then increased and stabilized after $70 \mathrm{kyr}$, reaching modstudies suggested that the climate system ern levels sometime after $60 \mathrm{kyr}$ (Scholz et al., 2007). Similar findings are observed in data from Lake Tanganyika and Lake Bosumtwi (West Africa). Surprisingly, the early late-Pleistocene lake-level lowstands and megadroughts were much more severe than the low lake stages observed during the Last Glacial Maximum in all three of these tropical lakes. The termination of the high climate variability interval that included the megadroughts may have played an important role in the final African exodus and population expansion of Early Modern Humans (Scholz et al., 2007).

It appears that in tropical East Africa, the climate forcing underwent a mode switch after $\sim 70 \mathrm{kyr}$, from eccentricitymodulated precessional control, to one linked to high-latitude climate shifts. Initial results of scanning $X$-ray fluorescence (XRF) data from the north basin drill site in Lake Malawi suggest that rapid shifts in climate over the past $\sim 55 \mathrm{kyr}$ are related to abrupt warming (Dansgaard-Oeschger) events observed in Greenland (Brown et al., 2006).

\section{Acknowledgements}

Funding for the program was provided by the U.S. NSF Earth Systems History Program, and from the International Continental Scientific Drilling Program (ICDP). Further information and images from the project can be found at http://malawidrilling.syr.edu/.

\section{References}

Scholz, C. A, Johnson, T. C Cohen, AS, King, JW, Peck, J Overpeck, J.T., Talbot, M.R., Brown, E.T., Kalindekafe, L., Amoako, P.Y.O, Lyons, R.P, Shanahan, T.M., Castaneda, I.S., Heil, C.W., Forman, S.L., McHargue, L.R., Beuning, K.R., Gomez, J. and Pierson, J., in press: East African megadroughts between 135-75 kyr ago and bearing on early-modern human origins, Proceedings of the National Academy of Sciences, www.pnas.org/cgi/doi/10.1073/ pnas.0703874104.

Brown, E.T., Johnson, T.C., Scholz, C.A., King, J. and Cohen, A.S., 2006 D-0 Events in the Southern Tropics of East Africa? Initial XRF Results From the Lake Malawi Drilling Project, Eos Transactions of the American Geophysical Union, 87(52): Fall Meeting Supplement, Abstract PP13A-1587. 